\title{
(2) \\ AGRONOMIC PERFORMANCE AND PEST RESPONSE OF DIFFERENT MUNGBEAN (VIGNA RADIATA L.) GENOTYPES PLANTED DURING DRY SEASON CROPPING IN LEYTE, PHILIPPINES
}

\author{
Tricia Mae 0. HILVANO ${ }^{1}$, Ulysses CAGASAN ${ }^{1 *}$ \\ ${ }^{1}$ Department of Agronomy, Visayas State University, Visca, Baybay City, Leyte 6521-A, Philippines
}

\begin{abstract}
High yielding and pest resistant varieties are among the characteristics of the crops that the farmers are looking. This study aimed to evaluate, determine and assess the profitability of different mungbean genotypes planted during dry season cropping. An experimental area of $416.5 \mathrm{~m}^{2}$ was laid out in Randomized Complete Block Design (RCBD) with ten (10) treatments replicated 3 times. Each treatment plot had an area of $2.0 \mathrm{~m} \mathrm{x} 5.0 \mathrm{~m}\left(10 \mathrm{~m}^{2}\right)$ with four rows in each plot. The treatments designated as follows: $\mathrm{T}_{1}=\mathrm{EGM}$ 98-419, $\mathrm{T}_{2}=$ LG Mg 28-6-0, $\mathrm{T}_{3}=$ LG Mg 28-6-1, $\mathrm{T}_{4}=$ LG Mg 28-7-1, $\mathrm{T}_{5}=$ Jade Green, $\mathrm{T}_{6}=\mathrm{EGM}$ 98-391, $\mathrm{T}_{7}=\mathrm{EGM}$ 05-738, $\mathrm{T}_{8}=\mathrm{EGM}$ 05$744, \mathrm{~T}_{9}=$ NSIC Mg 17, and $\mathrm{T}_{10}=$ PAG- ASA 7. Results revealed that most of the agronomic characteristics of different mungbean genotypes were significantly affected by the different genotypes such as days from sowing to emergence, flowering, maturity and plant height $(\mathrm{cm})$. The genotype EGM 98-419 $\left(\mathrm{T}_{1}\right)$ emerge earlier compared to others while PAG-ASA $7\left(\mathrm{~T}_{10}\right)$ flowers early than the other treatments. On the other hand, EGM 98-391 ( $\left.\mathrm{T}_{6}\right)$ was the early genotype to mature. However, highest plant height $(\mathrm{cm})$ was obtained from the genotypes LG Mg 28-6-0 ( $\left.\mathrm{T}_{2}\right)$, LG Mg 28-6-1 ( $\left.\mathrm{T}_{3}\right)$, LG Mg 28-7-1 $\left(\mathrm{T}_{4}\right)$ and Jade Green $\left(\mathrm{T}_{5}\right)$. Likewise, number of pods per plant and seed yield were significantly affected by the different mungbean genotypes. Highest number of pods were observed from the genotype LG Mg 28-7-1 $\left(\mathrm{T}_{4}\right)$ and also obtained the highest seed yield of $1.47 \mathrm{tha}^{-1}$ compared to other genotypes. Highest gross margin of PhP 69622.00 was obtained from LG Mg 28-7-1 (T4) and obtained the highest grain yield. Pest response of all mungbean genotypes were highly resistant to insect pest and moderately resistant to diseases.
\end{abstract}

Keywords: Cultivars, Yield performance, Pest resistance, Insect and diseases, Cropping season, Stability

\begin{tabular}{|c|c|c|}
\hline \multicolumn{3}{|c|}{ *Corresponding author: Department of Agronomy, Visayas State University, Visca, Baybay City, Leyte 6521-A, Philippines } \\
\hline \multicolumn{3}{|c|}{ E mail: ulycagasan@vsu.edu.ph (U.CAGASAN) } \\
\hline Tricia Mae 0 . HILVANO & https://orcid.org/0000-0001-7773-2101 & Received: April 09, 2020 \\
\hline Ulysses CAGASAN & https://orcid.org/0000-0001-7773-2101 & $\begin{array}{l}\text { Accepted: April 14, } 2021 \\
\text { Published: July 01, } 2021\end{array}$ \\
\hline
\end{tabular}

Cite as: Hilvano TMO, Cagasan U. 2021. Agronomic performance and pest response of different mungbean (Vigna radiata L.) genotypes planted during dry season cropping in Leyte, Philippines. BSJ Agri, 4(3): 97-102.

\section{Introduction}

Mungbean (Vigna radiata L.) is an important legume crop providing vegetable protein for the people throughout Asia (Halimi, et al., 2018). Its dry seeds and fresh green young pods are consumed as vegetables due to its high protein, vitamin and mineral content. Its herbage is used as forage for livestock (Tang et al., 2014). It is used as intercrop in dry and semi-dry regions because of its drought tolerance and nitrogen-fixing abilities (Clua, et al., 2018).

Mungbean is famous as "tawgi" or sprouts and used as raw material in sotanghon manufacturing, hopia making, and ingredients in soups, porridge, bread, noodles and ice cream. It is also beneficial to human health as cholesterol controller, bone strengthener, blood pressure regulator, liver protection, promotes growth to children, anti-viral and anti-cancerous agent (http://www.stylecraze.com/articles/amazing-benefitsof-mung-beans/), thus, high demand for this commodity. In the Philippines, Bureau of Agricultural Statistics reported that the highest volume of production for the past five years was obtained in 2017, with 45283 metric tons from the total production area of 44324 hectares. In 2018, however production area declined to 32364 hectares with total production of 32364 metric tons, (PSA, 2018). However, national average yield per hectare remains low (0.73 metric tons). Hence, development of more high yielding NSIC varieties is needed.

Planting genotypes adapted to our geographic situation increase crop productivity. Seed Alliance (2018) reported that on-farm trials help the farmers to manage risk and help growers to optimize their operation to avoid a number of common production problems. In this regard, promising mungbean genotypes is needed to be evaluated on their agronomic performance during dry season where mungbean can provide good harvest during this season (Mondal, 2011). Another one important traits of a good variety is its resistance to pest and diseases thus, the response of the different mungbean lines is needed under different agro-climatic conditions before its recommendation to the National Seed Industry Council for release as new variety. Hence, 


\section{Black Sea Journal of Agriculture}

this study was conducted to determine the performance of the different promising mungbean genotypes in terms of growth, yield and pest response.

\section{Material and Methods}

An area of Umingan clay loam soil, (FAO, 2013) located at the Agronomy Experimental Area College of Agriculture and Food Science, Visayas State University, Babay City, Leyte. The experimental area has a GPS coordinates of $10^{\circ} 44^{\prime} 59.8668^{\prime \prime} \mathrm{N}, 124^{\circ} 47^{\prime} 38.1264^{\prime \prime} \mathrm{E}$. This was plowed and harrowed twice at weekly interval to provide desirable soil tilth for better growth and development of plant. Furrows were made immediately after the last harrowing at a spacing of $0.5 \mathrm{~m}$.

Before land preparation, ten soil samples were collected randomly in the experimental area at $15-20 \mathrm{~cm}$ depth. Samples were collected air-dried and sieved through 2 $\mathrm{mm}$ wire mesh and brought to the Central Analytical Services Laboratory (CASL), Phil Rootcrops, Visca, Baybay City, Leyte for the initial and final determination of $\mathrm{pH}$ (potentiometric method), organic matter (WalkleyBlack Method), total N, extractable phosphorus (Olsen's sodium bicarbonate extraction) and exchangeable potassium at the using the ammonium acetate extraction method.

The experimental area was laid out in a Randomized Complete Block Design (RCBD) with three replications following the protocol of conducting NCT trials for legumes. Each replication was divided into ten treatment plots each measuring $2 \mathrm{~m} \times 5 \mathrm{~m}\left(10 \mathrm{~m}^{2}\right)$ with four rows per plot. Alleyways of $1 \mathrm{~m}$ between replications and $0.5 \mathrm{~m}$ between treatment plots were provided to facilitate farm operations and data gathering. The following mungbean genotypes evaluated and served as the treatments of the study, were the following: $\mathrm{T}_{1}=\mathrm{EGM} 98-419, \mathrm{~T}_{2}=\mathrm{LG} \mathrm{Mg}$ 28-6-0, $\mathrm{T}_{3}=\mathrm{LG}$ Mg 28-6-1, $\mathrm{T}_{4}=\mathrm{LG}$ Mg 28-7-1, $\mathrm{T}_{5}=\mathrm{Jade}$ Green, $\mathrm{T}_{6}=\mathrm{EGM}$ 98-391, $\mathrm{T}_{7}=\mathrm{EGM}$ 05-738, $\mathrm{T}_{8}=\mathrm{EGM}$ 05744, $\mathrm{T}_{9}=$ NSIC Mg 17, $\mathrm{T}_{10}=$ PAG- ASA 7. Seeds of mungbean genotype specified in the treatments were evenly drilled in furrows in each assigned treatment plot. The seeds were covered with thin layer of soil to protect them from ants and birds that may feed on them and disrupt their growth. Thinning was done ten days after seeding in all treatment plots to achieve the desired plant population of 150000-200000 ha-1. Complete fertilizer (14-14-14) was applied at the rate of 30-30-30 kg ha-1 $\mathrm{N}$, $\mathrm{P}_{2} \mathrm{O}_{5}, \mathrm{~K}_{2} \mathrm{O}$. About 214. 29 grams of complete fertilizer was applied in each treatment plot. The fertilizer was placed in furrows and covered with fine layer of soil about 2-3 $\mathrm{cm}$ thick to prevent the seedlings from getting in contact with the fertilizer. The application of fertilizer was done 5-7 days after seedling emergence.

Six weeks after planting, aphids and Cercospora leaf spot disease were observed. No control measure was done to the study since pest resistance parameters were observed and evaluated in the study. The mungbean crop was harvested when about $75 \%$ of the pods in each treatment plot reached physiological maturity characterized by black or brown color of pods. All the plants in harvestable area $\left(4.0 \mathrm{~m}^{2}\right)$ of each treatment plots were harvested excluding the two boarder rows. The sample pods in each treatment plots were sundried for three days before necessary data were gathered. For the agronomic characteristics; days from seeding to seedling emergence, days from seeding to flowering, days from seeding to maturity, plant height $(\mathrm{cm})$ at harvest, fresh herbage yield $\left(\mathrm{t} \mathrm{ha}^{-1}\right)$. The plot yield was converted to ton hectare ${ }^{-1}$ using the formula (equation 1 ):

$H Y\left(t h a^{-1}\right)=\frac{P Y(k g)}{H A(4.0 \mathrm{~m} 2)} \times \frac{10000 \mathrm{~m}^{2} h a^{-1}}{1000 \mathrm{~kg} \mathrm{t}^{-1}}$

HY= Herbage yield, PY= Plot yield and HA= Harvestable area.

For yield and yield components; number of pods plant ${ }^{-1}$, number of seeds pod-1, weight of seeds plant ${ }^{-1}$, weight of 1000 seeds $(\mathrm{g})$ and seed yield ( $\mathrm{t} \mathrm{ha}^{-1}$ ) was weighed and converted to hectare ${ }^{-1}$ using the formula (equation 2 ):

$Y\left(t h a^{-1}\right)=\frac{P Y(k g)}{H A\left(4.0 \mathrm{~m}^{2}\right)} \times \frac{10000 \mathrm{~m}^{2} \mathrm{ha}^{-1}}{1000 t h a^{-1}}$

Y= Yield, PY= Plot yield and HA= Harvestable area.

For the pest resistance rating the NCT pest rating manual for legumes (2017) was used. This was determined through the use of a rating scale from 1-5, one is the lowest rating of pests and diseases present in the field while five is the rating that indicated severe number of insect pests and diseases present in the field. Ratings for insect pests was done by selecting (at random) ten sample plants per plot and examine them thoroughly for leaf feeding damage at 25 days after emergence (NCT Manual for Legumes, revised 2017). Other parameters gathered were harvest index (HI), gross margin analysis and meteorological. These were determined using the formula, below (equation 3):

$H I=\frac{D W G(3 \text { sample plants })}{D W H+D W G(3 \text { sample plants })}$

$\mathrm{HI}=$ Harvest index, DWG $=$ Dry weight of grains and DWH= Dry weight of herbage.

Gross Margin = Gross Income - Total Variable Cost.

Meteorological Data such as total monthly rainfall (mm), average daily minimum and maximum temperatures $\left({ }^{\circ} \mathrm{C}\right)$ and relative humidity (\%) throughout the conduct of the study were taken from the records of Philippine Atmospheric, Geophysical and Astronomical Services Administration (PAGASA) Station, VSU, Visca, Baybay City, Leyte. Likewise, Cost and return was also computed to test the profitable treatment/ mungbean genotypes.

Means were taken and ANOVA was done using Statistical Tool for Agricultural Research (STAR) software. Comparison between treatments was done using the Honestly Significant Difference (HSD). 


\section{Results and Discussion}

The climatic data is presented in (Figure 1). The climatic data (total amount of rainfall $(\mathrm{mm})$, minimum and maximum temperatures as well as the percent relative humidity received by the mungbean plants were enough for its normal growth and development, (PCARRD Handbook, 2002).

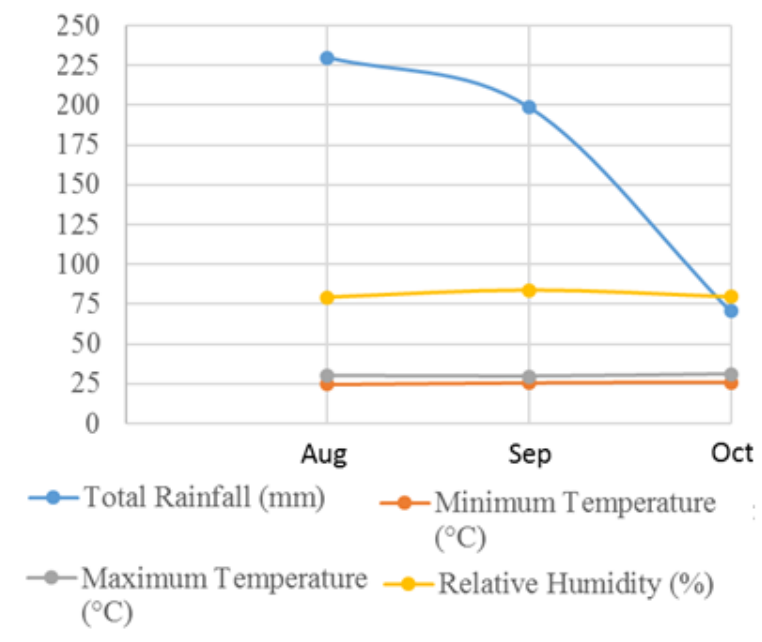

Figure 1. Total monthly rainfall $(\mathrm{mm})$, average minimum and maximum temperature $\left({ }^{\circ} \mathrm{C}\right)$ and relative humidity from August 16, 2018 to October 24, 2018 obtained from PAGASA Station, VSU, Visca, Baybay City, Leyte.

\subsection{Soil Analysis}

Results of initial soil analysis showed a $\mathrm{pH}$ of 6.17 , with $1.897 \%$ of organic matter, $0.167 \%$ of total Nitrogen, $16.043 \mathrm{mg} \mathrm{kg}^{-1}$ available Phosphorus and 0.618 me 100 $\mathrm{g}^{-1}$ exchangeable potassium (Table 1 ). These indicated that the soil was slightly acidic with high amount of phosphorus, very low amount in organic matter and low amount of both nitrogen and potassium (Landon, 1991).

Table 1. Soil chemical analyses before and after planting of mungbean genotypes grown in dry season cropping

\begin{tabular}{lcc}
\hline & $\begin{array}{c}\text { Initial analysis } \\
\text { (before planting) }\end{array}$ & $\begin{array}{c}\text { Final analysis } \\
\text { (after planting) }\end{array}$ \\
\hline Soil pH & 6.17 & 5.48 \\
\% OM & 1.897 & 1.845 \\
Total N (\%) & 0.167 & 0.152 \\
Available P & 16.043 & 25.300 \\
(mg kg- $^{-1}$ ) & & \\
Exchangeable & 0.618 & 0.633 \\
K (me 100 g-1) & & \\
\hline
\end{tabular}

In the final soil analysis, the soil $\mathrm{pH}$ slightly decreased to 5.48. The organic matter and total nitrogen also decreased from 1.897 to $1.845 \%$ and 0.167 to $0.152 \%$, respectively. The decrease in soil $\mathrm{pH}$ can be due to due to leaching from high amounts of rainfall. Likewise, there was a decrease in total nitrogen and organic matter and this could be attributed to the consumption of nutrients by the plants (Baldock, 2019). To the contrary, sufficient amount of available phosphorus and exchangeable potassium was observed. This could be due to the added fertilizers into the experimental area and decomposition of leaf litter and other plant herbage that were previously planted in the area (Singh, 2017).

\subsection{Agronomic Characteristics of Mungbean}

Table 2 show the agronomic characteristics of mungbean as affected by the different promising genotypes of mungbean. Analysis of variance showed that the number of days from seeding to emergence, flowering, maturity, plant height $(\mathrm{cm})$ and fresh herbage yield $\left(\right.$ tha $\left.^{-1}\right)$ were significantly affected by the different mungbean genotypes. Among the genotypes tested, EGM 98-419 $\left(\mathrm{T}_{1}\right)$ emerged earlier and this was comparable to $\mathrm{LG} \mathrm{Mg}$ 28-6-0 ( $\left.\mathrm{T}_{2}\right)$, LG Mg 28-6-1 ( $\left.\mathrm{T}_{3}\right)$, LG Mg 28-7-1 ( $\left.\mathrm{T}_{4}\right)$, EGM 98-391 ( $\mathrm{T}_{6}$ ), EGM 05-738 ( $\left.\mathrm{T}_{7}\right)$ and PAG-ASA 7 ( $\left.\mathrm{T}_{10}\right)$ while, EGM 05-744 ( $\left.\mathrm{T}_{8}\right)$, NSIC Mg $17\left(\mathrm{~T}_{9}\right)$ and Jade Green ( $\left.\mathrm{T}_{5}\right)$ were late to emerged. This result can be attributed to the inherent characteristics of mungbean. According to Rehman et al. (2009), different varieties have different genotypic characteristics which resulted to the difference in agronomic and yield performance.

On the other hand, early flowering was obtained by the genotype PAG-ASA $7\left(\mathrm{~T}_{10}\right)$ and this was comparable to EGM 98-419 ( $\left.\mathrm{T}_{1}\right)$, Jade Green ( $\left.\mathrm{T}_{5}\right)$ EGM 98-391 ( $\left.\mathrm{T}_{6}\right)$, and EGM 05-738 ( $\left.\mathrm{T}_{7}\right)$, Mondal et al. (2011) reported that flowering duration was higher in high yielding varieties than the low yielding ones. In addition, flowering duration and flower production had relation with seed yield in mungbean. Furthermore, the genotype EGM 98$391\left(\mathrm{~T}_{6}\right)$ and PAG-ASA $7\left(\mathrm{~T}_{10}\right)$ were considered early maturing among the rest of the treatments. However, EGM 98-419 $\left(\mathrm{T}_{1}\right)$ was considered late maturing genotype which was comparable to genotypes LG Mg 28-6-1 ( $\left.\mathrm{T}_{3}\right)$, LG Mg 28-7-1 ( $\left.\mathrm{T}_{4}\right)$ and NSIC Mg 17 ( $\left.\mathrm{T}_{9}\right)$. Again this could be accounted to the characteristics of the genotypes (Rehman et al., 2019). Moreover, taller mungbean plants were noted from the genotypes Jade Green $\left(\mathrm{T}_{5}\right)$, and comparable to LG Mg 28-6-1 ( $\left.\mathrm{T}_{3}\right)$, LG Mg 28-6-0 ( $\left.\mathrm{T}_{2}\right)$, LG Mg 28-7-1 ( $\left.\mathrm{T}_{4}\right)$, NSIC Mg 17( $\left.\mathrm{T}_{9}\right)$, EGM 98-391 ( $\left.\mathrm{T}_{6}\right)$, EGM 98-419 ( $\left.\mathrm{T}_{1}\right)$ while EGM 05-738 ( $\left.\mathrm{T}_{7}\right)$, EGM 05-744 ( $\left.\mathrm{T}_{8}\right)$ and PAG-ASA $7\left(\mathrm{~T}_{10}\right)$ were significantly shorter due to different genotypic characteristics of the treatments tested.

\subsection{Yield, Yield Components and Harvest Index}

Table 3 show the yield and yield components and harvest index of mungbean as affected by the different promising genotypes of mungbean. Analysis of variance showed that number of pods per plant, and seed yield ( $\mathrm{t}$ ha-1) were significantly affected by the different treatments but not on the seeds per pod, weight of the seeds per plant, weight of 1000 seeds (g), and harvest index. The genotypes EGM 98-391 ( $\mathrm{T}_{6}$ ) produced higher number of pods comparable to the genotypes EGM 98-419 ( $\left.\mathrm{T}_{1}\right)$, EGM 05-744 ( $\mathrm{T}_{8}$ ), LG Mg 28-6-1 ( $\left.\mathrm{T}_{3}\right)$, LG Mg 28-7-1 ( $\left.\mathrm{T}_{4}\right)$, EGM 98-391 ( $\mathrm{T}_{6}$ ), EGM 05-738 ( $\mathrm{T}_{7}$ ), NSIC Mg 17 ( $\mathrm{T}_{9}$ ), and PAGASA $7\left(\mathrm{~T}_{10}\right)$. 
Black Sea Journal of Agriculture

Table 2. Agronomic characteristics of different mungbean genotypes grown in dry season cropping

\begin{tabular}{|c|c|c|c|c|c|}
\hline \multirow{2}{*}{ Treatment } & \multicolumn{3}{|c|}{ Days from seeding to } & \multirow{2}{*}{$\begin{array}{c}\text { Plant } \\
\text { Height }(\mathrm{cm})\end{array}$} & \multirow{2}{*}{$\begin{array}{c}\text { Fresh Herbage } \\
\left.\text { Yield ( } \mathrm{t} \mathrm{ha}^{-1}\right)\end{array}$} \\
\hline & Emergence & Flowering & Maturity & & \\
\hline $\mathrm{T}_{1}-\mathrm{EGM} 98-419$ & $2.67 \mathrm{c}$ & $35.00 \mathrm{bcd}$ & $61.33^{a}$ & $81.10^{\mathrm{cd}}$ & 7.92 \\
\hline $\mathrm{T}_{2}-\mathrm{LG} \mathrm{Mg}$ 28-6-0 & $3.00^{\mathrm{bc}}$ & $36.00^{\mathrm{b}}$ & $57.67 \mathrm{~cd}$ & $91.80^{\mathrm{abc}}$ & 9.09 \\
\hline $\mathrm{T}_{3}-\mathrm{LG}$ Mg 28-6-1 & $3.00^{\mathrm{bc}}$ & $38.67^{a}$ & $61.33^{\mathrm{a}}$ & $95.33^{\mathrm{ab}}$ & 7.71 \\
\hline $\mathrm{T}_{4}-\mathrm{LG} \mathrm{Mg} 28-7-1$ & $3.00^{\mathrm{bc}}$ & $35.67 \mathrm{bc}$ & $60.00^{\mathrm{ab}}$ & $85.47^{a-d}$ & 6.71 \\
\hline $\mathrm{T}_{5}$ - Jade Green & $3.67 \mathrm{ab}$ & $34.00^{\mathrm{cd}}$ & $58.00^{c}$ & $95.67 \mathrm{a}$ & 5.25 \\
\hline $\mathrm{T}_{6}-\mathrm{EGM} 98-391$ & $3.33^{\mathrm{abc}}$ & $34.67 \mathrm{bcd}$ & $55.67 \mathrm{e}$ & $81.60^{\mathrm{cd}}$ & 9.54 \\
\hline $\mathrm{T}_{7}-\mathrm{EGM} 05-738$ & $3.00^{\mathrm{bc}}$ & $35.00^{\mathrm{bcd}}$ & $59.00 \mathrm{bc}$ & $80.97 \mathrm{~cd}$ & 10.34 \\
\hline $\mathrm{T}_{8}-\mathrm{EGM} 05-744$ & $4.00^{\mathrm{a}}$ & $38.00^{a}$ & $58.33^{b c}$ & 76.93de & 10.79 \\
\hline $\mathrm{T}_{9}-\mathrm{NSIC} \mathrm{Mg} 17$ & $3.67 \mathrm{ab}$ & $39.00^{\mathrm{a}}$ & $60.00^{\mathrm{ab}}$ & $84.17 \mathrm{bcd}$ & 10.50 \\
\hline $\mathrm{T}_{10}-\mathrm{PAG}-\mathrm{ASA} 7$ & $3.00 \mathrm{bc}$ & $33.33^{d}$ & 56.00 de & $67.42^{\mathrm{e}}$ & 10.38 \\
\hline Mean & 3.23 & 35.93 & 58.73 & 84.04 & 8.82 \\
\hline C. V. \% & 9.78 & 11.90 & 11.05 & 14.62 & 28.06 \\
\hline
\end{tabular}

Means within each column followed by the same letter and those without letter designations were not significantly different at $5 \%$ level, HSD test.

Table 3. Yield and yield components and harvest index of different mungbean genotypes grown in dry season cropping

\begin{tabular}{|c|c|c|c|c|c|c|}
\hline \multirow{2}{*}{ Treatment } & \multicolumn{2}{|c|}{ Number of } & \multicolumn{2}{|c|}{ Weight (g) of } & \multirow{2}{*}{$\begin{array}{c}\text { Seed } \\
\text { Yield } \\
\left(\mathrm{t} \mathrm{ha}^{-1}\right)\end{array}$} & \multirow{2}{*}{$\begin{array}{c}\text { Harvest } \\
\text { Index }\end{array}$} \\
\hline & Pods per plant & Seeds per pod & Seeds per 1000 & Plant seeds & & \\
\hline $\mathrm{T}_{1}$ - EGM 98-419 & $25.67 \mathrm{a}$ & 11.77 & 9.87 & 69.67 & $1.17 \mathrm{ab}$ & 0.31 \\
\hline $\mathrm{T}_{2}-\mathrm{LG} \mathrm{Mg} 28-6-0$ & $15.67 \mathrm{~b}$ & 11.93 & 11.20 & 70.33 & $1.27^{\mathrm{a}}$ & 0.35 \\
\hline $\mathrm{T}_{3}-\mathrm{LG} \mathrm{Mg} 28-6-1$ & $24.67^{a}$ & 12.70 & 12.10 & 73.33 & $1.20^{\mathrm{ab}}$ & 0.36 \\
\hline $\mathrm{T}_{4}-\mathrm{LG} \mathrm{Mg} 28-7-1$ & $22.00^{\mathrm{ab}}$ & 12.29 & 13.83 & 70.33 & $1.47^{a}$ & 0.38 \\
\hline $\mathrm{T}_{5}$ - Jade Green & $15.67 \mathrm{~b}$ & 11.63 & 9.23 & 68.33 & $0.40^{c}$ & 0.33 \\
\hline $\mathrm{T}_{6}-\mathrm{EGM} 98-391$ & $26.00^{\mathrm{a}}$ & 12.47 & 11.93 & 70.00 & $1.33^{\mathrm{a}}$ & 0.34 \\
\hline $\mathrm{T}_{7}-\mathrm{EGM} 05-738$ & $21.33^{\mathrm{ab}}$ & 12.83 & 11.93 & 66.67 & $1.43^{\mathrm{a}}$ & 0.32 \\
\hline $\mathrm{T}_{8}-\mathrm{EGM}$ 05-744 & $25.33^{\mathrm{a}}$ & 13.03 & 12.00 & 70.33 & $1.43^{\mathrm{a}}$ & 0.33 \\
\hline $\mathrm{T}_{9}-\mathrm{NSIC} \mathrm{Mg} 17$ & $24.00^{\mathrm{a}}$ & 12.87 & 10.90 & 69.67 & $1.30^{\mathrm{a}}$ & 0.38 \\
\hline $\mathrm{T}_{10}-\mathrm{PAG}-\mathrm{ASA} 7$ & $23.67 \mathrm{ab}$ & 13.07 & 9.87 & 70.00 & $0.83^{\mathrm{bc}}$ & 0.31 \\
\hline Mean & 22.76 & 12.46 & 11.29 & 69.87 & 1.18 & 0.34 \\
\hline C. V. $\%$ & 12.45 & 13.98 & 16.08 & 13.66 & 24.67 & 12.86 \\
\hline
\end{tabular}

Means within each column followed by the same letter and those without letter designations were not significantly different at 5\% level, HSD test.

On the other hand, lesser number of pods were observed from the genotypes Jade ( $\mathrm{T}_{5}$ ) Green and LG Mg 28-6-0 $\left(\mathrm{T}_{2}\right)$ but comparable to LG Mg 28-7-1 ( $\left.\mathrm{T}_{4}\right)$, EGM 05-738 $\left(\mathrm{T}_{7}\right)$ and PAG-ASA 7 ( $\left.\mathrm{T}_{10}\right)$. On the other hand, comparable higher seed yield ( $\left.\mathrm{t} \mathrm{ha}^{-1}\right)$ were observed from all genotypes except Jade Green (0.40 $\left.\mathrm{tha}^{-1}\right)$ and PAG-ASA 7 (0.83 $\mathrm{t} \mathrm{ha}^{-1}$ ) which had the lowest seed yield among others. Mondal et al. (2011) added that mungbean varieties that produce more number of pods will also produce higher seed yield in per hectare basis.

\subsection{Response of Insect Pest and Diseases}

Response of different mungbean genotypes to insect pests and diseases is presented in (Table 4). Analysis of variance showed that the insect pest damage and disease did not show significant differences among treatment genotypes. This insignificant result could be due to their genotypic characteristics of the mungbean plants. All treatments were highly resistant to the insect damage. In addition, all genotypes tested were moderately susceptible to Cercospora leaf spot disease. In effect, this insect and disease damage did not affect the production of mungbean. Hence, they produce a reasonable yield except Jade Green $\left(\mathrm{T}_{5}\right)$ and PAG-ASA 7 ( $\left.\mathrm{T}_{10}\right)$.

Moreover, based on the reaction of insect pest damage of different mungbean genotypes the farmers can minimize the cost of insecticide due to it is highly resistance to insect pests.

\subsection{Gross Margin Analysis}

Gross margin analysis of mungbean in response to different genotypes is presented in Table 5 . Highest gross margin of $\mathrm{PhP} 69622.00$ ha $^{-1}$ was obtained from the genotype LG Mg 28-7-1 ( $\mathrm{T}_{4}$ ) followed by EGM 05-738 $\left(\mathrm{T}_{7}\right)$ and EGM 05-744 (T8) of PhP 66,822.00 ha-1. This was due to the high grain yield obtained in the said genotype. However, the genotype Jade Green generated the lowest gross margin of $\mathrm{PhP} 722.00$, due to the very low grain yield ( $\left.\mathrm{t} \mathrm{ha}^{-1}\right)$. 
Black Sea Journal of Agriculture

Table 4. Incidence of insect pests and diseases of different mungbean genotypes grown in dry season cropping

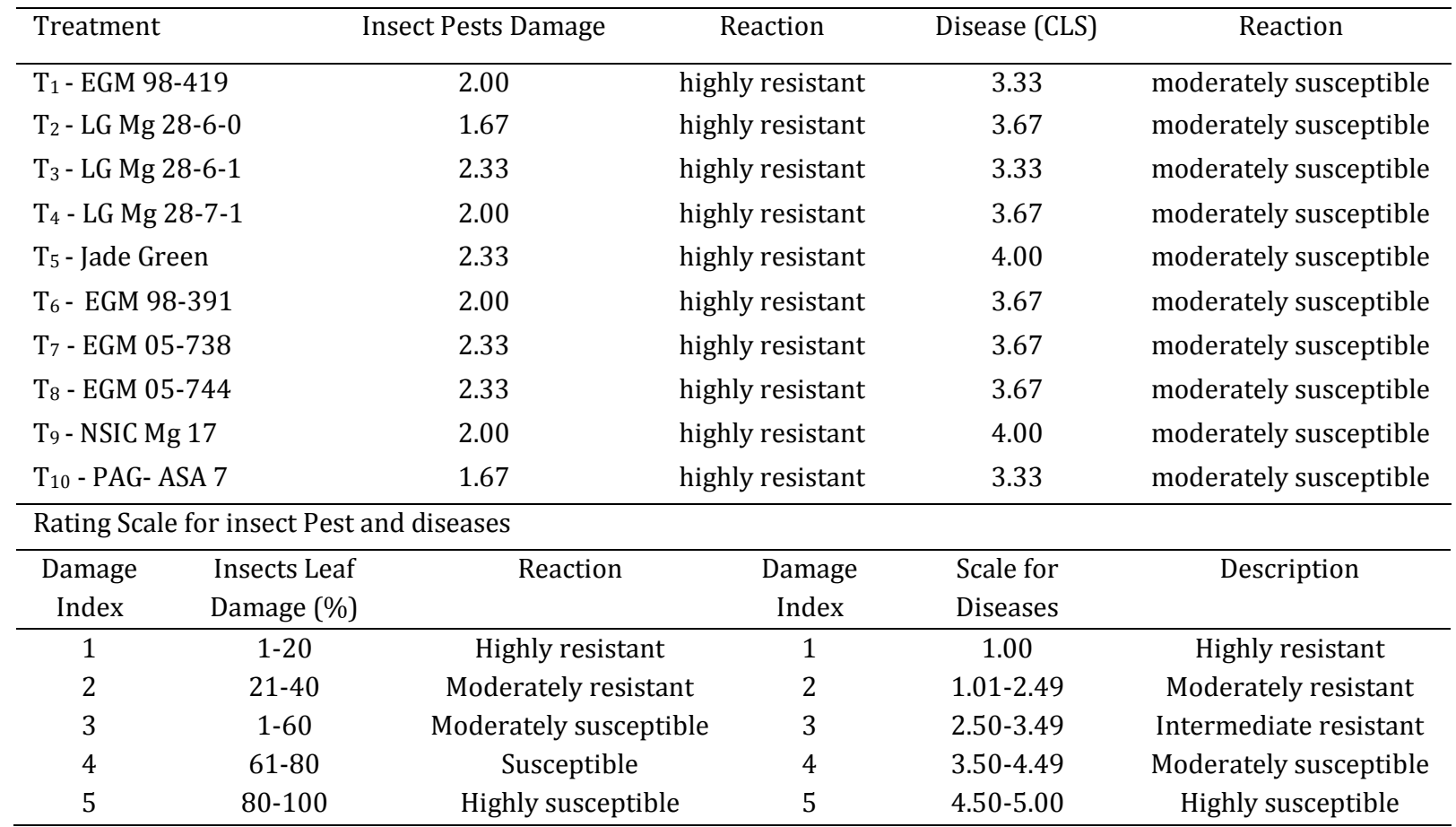

Table 5. Gross margin analysis of different mungbean genotypes grown in dry season cropping*

\begin{tabular}{lcccc}
\hline Treatment & $\begin{array}{c}\text { Grain yield } \\
\left(\mathrm{t} \mathrm{ha}^{-1}\right)\end{array}$ & $\begin{array}{c}\text { Gross } \\
\text { Income }\left(\mathrm{PhP} \mathrm{ha}^{-1}\right)\end{array}$ & $\begin{array}{c}\text { Production Cost } \\
\left(\text { PhP ha-1) }^{-}\right.\end{array}$ & $\begin{array}{c}\text { Net Income } \\
\left(\text { PhP ha }^{-1}\right)\end{array}$ \\
\hline $\mathrm{T}_{1}$ - EGM 98-419 & 1.17 & 81900.00 & 32528.00 & 49372.00 \\
$\mathrm{~T}_{2}$ - LG Mg 28-6-0 & 1.27 & 88900.00 & 32528.00 & 56372.00 \\
$\mathrm{~T}_{3}$ - LG Mg 28-6-1 & 1.20 & 84000.00 & 32528.00 & 51472.00 \\
$\mathrm{~T}_{4}$ - LG Mg 28-7-1 & 1.47 & 102900.00 & 33278.00 & 69622.00 \\
$\mathrm{~T}_{5}$ - Jade Green & 0.40 & 28000.00 & 27278.00 & 722.00 \\
$\mathrm{~T}_{6}$ - EGM 98-391 & 1.33 & 93100.00 & 33278.00 & 59822.00 \\
$\mathrm{~T}_{7}$ - EGM 05-738 & 1.43 & 100100.00 & 33278.00 & 66822.00 \\
$\mathrm{~T}_{8}$ - EGM 05-744 & 1.43 & 100100.00 & 33278.00 & 66822.00 \\
$\mathrm{~T}_{9}$ - NSIC Mg 17 & 1.30 & 91000.00 & 33278.00 & 57722.00 \\
$\mathrm{~T}_{10}$ - PAG- ASA 7 & 0.83 & 58100.00 & $27,278.00$ & 30822.00 \\
\hline
\end{tabular}

\section{Conclusion}

Results of the study found out that different genotypes of mungbean differ significantly in the number of days from sowing to emergence, number of days from sowing to flowering and maturity as well as the plant height. Likewise, and yield components such number of pods per plant and the total seed yield ( $\mathrm{t} \mathrm{ha}^{-1}$ ). Different mungbean genotypes yields ranges from 1.17-1.47 $\mathrm{t} \mathrm{ha}^{-1}$ ypes except Jade Green and PAG-ASA 7. Moreover, higher gross margins were obtained from all mungbean genotypes tested except Jade Green which obtain lower gross margin of $\mathrm{PhP} 722.00$ ha $^{-1}$ due to low yield per hectare. Likewise, based on the results of the study, it is recommended that a similar study be conducted in different locations to validate its performance across locations and seasons. While, one genotype Jade Green will be recommended to delete from the entries due to its very low performance in terms of yield.

\section{Author Contributions}

All authors have equal contributions and reviewed and approved the manuscript.

\section{Conflict of Interest}

The authors declare that there is no conflict of interest.

\section{References}

Baldock JL. 2019. Nitrogen and soil organic matter decline. Grains Research and Development Corporation. URL: https://grdc.com.au/resources-and-publications/grdc- 


\section{Black Sea Journal of Agriculture}

update-papers/tab-content/grdc-update-(access date: February 21, 2019).

Clua J, Roda C, Zanetti ME, Blanco FA. 2018. Compatibility between legumes and rhizobia for the establishment of a successful nitrogen-fixing symbiosis. Genes, 9(3): 125.

Degefa I, Petros Y, Argie M. 2014. Genetic variability heritability and genetic advance in mung bean (Vigna radiata L. Wilczek) accessions. Plant Sci Today, 1(2): 94-98.

FAO. 2013. FAOSTAT. Food and agriculture organization of the united nations. URL: http://www.fao.org/faostat/en/ (access date: February 21, 2019).

Halimi RA, Barkla BJ, Mayes S, King GJ. 2018. The potential of the underutilized pulse bambara groundnut (Vigna subterranea (L.) Verdc.) for nutritional food security. J Food Comp Anal, 77:47-59.

Landon JR. 1991. Booker tropical soil manual: A handbook for soil survey and agricultural land evaluation in the tropics and subtropics. Taylor \& Francis, New York, USA, pp 474.

Mondal MMA, Fakir MSA, Juraimi AS, Hakim MA, Islam MM, Shamsoddoha ATM. 2011. Effect of flowering behavior and pod maturity synchrony on yield of mungbean. Australian J Crop Sci, 5: 945-953.
Mondal MMA, Hakim MA, Juraimi AS, Azad MAK. 2011 Contribution of morpho-physiological attributes in determining yield of mungbean. African J Biotech, 10(60): 12897-12904.

NCT Manual for Legumes. Revised. 2017. Guidelines in conducting National Cooperative Testing in Field Legumes. Field legumes Technical Working Group. Bureau of Plant Industry. Diliman, Quezon City. Philippines.

PCARRD Handbook. 2002 PCARRD: Philippine council for agriculture, forestry, and natural resources research and development. Mungbean Varieties, Philippines, 11 pp.

Shirazy BJ, Rashid MH, Mahbub MM, Somee TA, Goswami PC 2016. Farmers' participatory demonstration of salt tolerant rice varieties in saline soils. Academic J Plant Sci, 9(1): 1-4.

Singh BN. 2017. What causes high levels of potassium. URL: http://www.researchgate.net/post/What_causes_high_levels _of_Potassium_in_a_forest_ecosystem/amp (access date: February 21, 2019).

Tang D, Dong Y, Ren H, He C. 2014. A review of photochemistry metabolite changes and medicinal uses of the common food mungbean and its sprouts (Vignaradiata). Chem Central J, 8: 4. 